\title{
PENGARUH GAYA BELAJAR DAN KECERDASAN LOGIKA MATEMATIKA TERHADAP PRESTASI BELAJAR MATEMATIKA
}

\author{
Dwi Santi Wulandari ${ }^{1}$, Indra Martha Rusmana ${ }^{2}$ \\ ${ }^{12}$ Program Studi Pendidikan Matematika, FMIPA, Universitas Indra Prasta PGRI Jakarta \\ dwiw5220@gmail.com ${ }^{1}$, indramartharusmana@ymail.com ${ }^{2}$
}

\begin{abstract}
The research objective is to analyze whether there is an influence of learning style and mathematical logic intelligence on mathematics learning achievement in Jatinegara District. The sample in this study were 60 students. Survey method with simple random sampling technique. The validity test of the two data indicates $r$ count $>r$ table (0.396) are valid. Reliability for Learning Styles is 0.92 and Mathematical Logic Intelligence is 0.86. Furthermore, the chi-square test, Calculate with criteria x2calculate $>x 2$ table consist of, namely Learning Style $(2.13<12.592)$, Logic Intelligence (10.25 <12.592), and Learning Achievement $(10.41<12.592)$, Computation gives result that data in normally distributed. The independent variable test partially on the dependent variable, (2.39>2.0042) then $H_{0}$ was rejected, and it was concluded that there was a significant influence of learning styles on mathematics learning achievement. (7.18> 2.0042) then $H_{0}$ is rejected, and it is concluded that there is a significant influence of Mathematical Logic Intelligence on Mathematics Learning Achievement. Multiple correlation test with $\alpha=0.05$ then $d b_{1}=2$ and $d b_{2}=$ 57 obtained $F_{\text {tabel }}=3.17$ and $F_{\text {hitung }}=607.33$; then $H_{0}$ is rejected and concluded that there is a significant influence of Learning Style and Mathematical Logic Intelligence together on Mathematics Learning Achievement.
\end{abstract}

Keywords: Learning Style, Mathematical Logic Intelligance, Mathematics Learning Achievement.

\begin{abstract}
Abstrak
Tujuan penelitian adalah untuk menganalisa apakah terdapat pengaruh gaya belajar dan kecerdasan logika matematika terhadap prestasi belajar matematika di Kecamatan Jatinegara. Sampel dalam penelitian ini adalah 60 peserta didik. Metode survei dengan teknik simple random sampling. Uji validitas kedua datanya menandakan $\mathrm{r}_{\text {hitung }}>\mathrm{r}_{\text {tabel }}(0,396)$ maka soal dikatakan valid. Reliabilitas untuk Gaya Belajar adalah 0,92 dan Kecerdasan Logika Matematika adalah 0,86. Selanjutnya uji chi-kuadrat, ketiga data menandakan $X^{2}{ }_{\text {hitung }}<X^{2}{ }_{\text {tabel, }}$ yaitu Gaya Belajar $(2,13<12,592)$, Kecerdasan Logika $(10,25<12,592)$, dan Prestasi Belajar $(10,41<12,592)$, maka ketiga datanya berdistribusi normal. Uji variabel bebas secara parsial terhadap variabel terikat, $(2,39>2,0042)$ maka $\mathrm{H}_{0}$ ditolak, dan disimpulkan terdapat pengaruh yang signifikan gaya belajar terhadap prestasi belajar matematika. $(7,18>2,0042)$ maka $\mathrm{H}_{0}$ ditolak, dan disimpulkan terdapat pengaruh yang signifikan Kecerdasan Logika Matematika terhadap Prestasi Belajar Matematika. Uji korelasi ganda dengan $\propto=0,05$ maka $\mathrm{db}_{1}=2$ dan $\mathrm{db}_{2}=57$ diperoleh $\mathrm{F}_{\text {tabel }}=3,17$ dan $\mathrm{F}_{\text {hitung }}=607,33 ;$ maka $\mathrm{H}_{0}$ ditolak dan disimpulkan bahwa terdapat pengaruh yang signifikan Gaya Belajar dan Kecerdasan Logika Matematika secara bersama- sama terhadap Prestasi Belajar Matematika.
\end{abstract}

Kata kunci: Gaya Belajar, Kecerdasan Logika Matematika, Prestasi Belajar Matematika 
Jurnal Lebesgue : Jurnal Ilmiah Pendidikan Matematika, Matematika dan Statistika

Dwi Santi Wulandari, Indra Martha Rusmana

Volume 1, No. 2, Agustus 2020 hal.76-81

DOI Artikel : 10.46306/lb.v1i2.18

\section{PENDAHULUAN}

Pendidikan adalah usaha sadar dan terencana untuk mewujudkan suasana belajar dan proses pembelajaran agar peserta didik secara aktif mengembangkan potensi dirinya untuk memiliki kekuatan spiritual keagaaman, pengendalian diri, kepribadian, kecerdasan, akhlak mulia, serta keterampilan yang diperlukan dirinya, masyarakat, dan Negara. Untuk mencapai tujuan pembelajaran matematika, dalam kegiatan pembelajaran perlu adanya suatu pembelajaran yang mampu mendorong siswa belajar secara aktif agar dapat belajar secara logis dan jujur, sehingga matematika dapat dengan mudah dipahami oleh siswa(Supriyanti, 2020)

Tingkat pendidikan seseorang memberi pengaruh terhadap kemungkinan seseorang tersebut menjadi pengangguran dan terjebak dalam kemiskinan. Sehingga perlulah mengejar pendidikan setinggitingginya(Kusuma \& Hamidah, 2019) sehingga Kegiatan belajar merupakan kegiatan yang pokok. Salah satu pendidikan yang penting untuk dipelajari adalah matematika. Matematika adalah ilmu yang digunakan manusia dalam kehidupan sehari-hari (Siagian, 2012: 123). Menurut Basuki (2015, 121) metematika menunjang dalam keberlangsungan hidup manusia dan menjadi alasan bagi manusia matematika harus dipelajari. Pentingnya mata pelajaran matematika menjadikannya sebagai salah satu mata pelajaran yang diujikan dalam kelulusan sekolah, baik Sekolah Dasar (SD), Sekolah Menengah Pertama (SMP), Sekolah Menengah Atas (SMA), dan Sekolah Menengah Kejuruan (SMK). Noveradila dalam Permana (2014: 238) menyatakan banyak anak-anak yang tidak menyukai pelajaran matematika dan cenderung takut untuk mempelajari mata pelajaran matematika. Didukung oleh pendapat Supardi (2014: 81) yang menyatakan bahwa banyak peserta didik masih menganggap pelajaran matematika merupakan pelajaran yang sulit, penuh perhitungan dan memusingkan, banyak rumus, simbol, angka, serta pelajaran yang membosankan, sehingga menimbulkan sikap malas belajar yang ditunjukkan peserta didik di dalam kelas.

Memecahkan masalah matematika tidak hanya membantu siswa membangun koneksi matematika, tetapi juga menunjukkan gaya berpikir matematis mereka. Dalam kemampuan memecahkan masalah konsep abstrak, peserta didik melibatkan juga gaya berpikir matematika peserta didik. Munculnya anggapan bahwa matematika pelajaran yang sulit adalah karena pelajaran tersebut memerlukan kecepatan berhitung dan kemampuan menghafal. Faktor internal dan eskternal yang saling berkaitan di antaranya:motivasi, kecerdasan, emosional, kecerdasan logika matematika, rasa percaya diri, kemandirian dan sikap, sarana, prasarana, lingkungan, dan cara mengajar (Vandini, 2015: 211). Salah satu faktor internal yang memiliki pengaruh dalam pembelajaran matematika adalah kecerdasan logika matematika.

Kecerdasan logika matematika dikategorikan sebagai kecerdasan akademik, karena dukungannya yang tinggi dalam keberhasilan studi seorang individu. Dalam tes IQ (Intelligence Quotient) atau kecerdasan intelektual menjadikan kecerdasan logika matematika sebagai indikator dalam tes tersebut. Menurut Musfiroh dalam Supardi (2014: 82) tes IQ mengutamakan kecerdasan logika matematika. Menurut Supardi (2014: 82) tingkat kecerdasan adalah secara ilmiah dianugerahi oleh Tuhan. Dapat 
Jurnal Lebesgue : Jurnal Ilmiah Pendidikan Matematika, Matematika dan Statistika

Dwi Santi Wulandari, Indra Martha Rusmana

Volume 1, No. 2, Agustus 2020 hal.76-81

DOI Artikel : 10.46306/lb.v1i2.18

disimpulkan bahwa setiap individu ternyata memiliki potensi kecerdasan logika matematika. Tinggal bagaimana orangtua dan guru dapat mengembangkan kecerdasan tersebut sejak usia dini. Dalam penyelesaian dan pemahaman matematika memerlukan konsentrasi yang tinggi. Situasi dan kondisi untuk berkonsentrasi berhubungan dengan gaya belajar. Faktor internal lain yang turut berkontribusi dalam pencapaian hasil belajar peserta didik yaitu gaya belajar.

Menurut Nasution dalam Prabasari dan Subowo (2017: 549) gaya belajar peserta didik merupakan cara mereka bereaksi dan menggunakan perangsang-perangsang yang diterimanya dalam proses belajar. Gaya belajar merupakan faktor penting yang mampu mempengaruhi prestasi akademik peserta didik, namun penerapan gaya belajar di dalam proses belajar mengajar sering dilupakan (Keliat, 2016: 2). Tanpa gaya belajar maka proses mengajar tidak akan berlangsung dengan baik. Semakin banyak gaya belajar yang dikuasai peserta didik, maka semakin baik proses belajar mengajar yang terjadi. Pentingnya mengetahui gaya belajar tidak membuat peserta didik lebih pandai, namun, dapat membantu peserta didik untuk menentukan cara belajar yang lebih efektif. Jika peserta didik mengetahui dan mengenali gaya belajarnya sendiri, maka peserta didik tersebut dapat mengelola pada kondisi apa, di mana, dan bagaimana ia dapat memaksimalkan belajar. Menurut Sezgin dalam Syawahid dan Putrawangsa (2017: 225) salah satu faktor keberhasilan peserta didik dalam pencapaian hasil belajar ditentukan dari gaya belajar. Setiap individu antara satu dengan lainnya memiliki perbedaan dalam hal gaya belajar. Beberapa peserta didik mengandalkan pendengaran (audio), penglihatan (visual), dan praktek langsung (kinestetik). Untuk lebih mengoptimalkan prestasi belajar maka kita perlu mengetahui ke dalam tipe manakah kita, audiotori, visual, atau kinestetik. Peserta didik yang mengetahui gaya belajar yang cocok untuknya, maka dapat memahami materi yang disampaikan oleh guru.

\section{METODE PENELITIAN}

Jenis penelitian ini adalah penelitian survei dengan pendekatan kuantitatif. Menurut Sugiyono (2017: 142) metode survei digunakan untuk mendapatkan data ditempat tertentu yang alamiah, tetapi peneliti melakukan perlakuan dalam pengumpulan data menggunakan Simple Random Sampling, misalnya dengan membagikan angket, melakukan tes, wawancara, dan sebagainya. Data-data penelitian diperoleh berdasarkan pemberian angket gaya belajar, pemberian tes untuk kecerdasan logika matematika, dan pengambilan hasil UTS untuk prestasi belajar matematika.Teknik pengambilan sampel.Menurut Sugiyono (2017: 137) pengumpulan data dapat dilakukan dalam berbagai sumber dan berbagai cara. Data untuk penelitian ini dikumpulkan dengan cara:

a. Teknik pengumpulan data Gaya Belajar pada pelajaran matematika

Teknik pengumpulan data Gaya Belajar dilakukan dengan cara menyebarkan kuesioner kepada peserta didik yang menjadi sampel penelitian.

b. Teknik pengumpulan data Kecerdasan Logika Matematika pada pelajaran matematika.

Teknik pengumpulan data Kecerdasan Logika Matematika dilakukan dengan cara memberikan tes kepada peserta didik yang menjadi sampel penelitian. 
Jurnal Lebesgue : Jurnal Ilmiah Pendidikan Matematika, Matematika dan Statistika

Dwi Santi Wulandari, Indra Martha Rusmana

Volume 1, No. 2, Agustus 2020 hal.76-81

DOI Artikel : 10.46306/lb.v1i2.18

c. Teknik pengumpulan data Prestasi Belajar Matematika

Teknik pengumpulan data Prestasi Belajar Matematika dengan cara diperoleh dari nilai UTS yang diadakan dari pihak sekolah.

Instrumen dalam penelitian ini yaitu nilai UTS dan angket (kuesioner). Tes untuk mengumpulkan data tentang Kecerdasan Logika Matematika siswa, angket untuk mengumpulkan data tentang Gaya Belajar siswa, dan nilai UTS untuk Prestasi Belajar Matematika.

\section{HASIL DAN PEMBAHASAN}

Data pada penelitian ini ada tiga yaitu data tentang Gaya Belajar peserta didik, Kecerdasan Logika Matematika dan Prestasi Belajar Matematika kelas IV (empat) SD Negeri Jatinegara Kaum 06 dan SD Negeri Jatinegara Kaum 07 tahun ajaran 2018/2019. Data Gaya Belajar bersumber dari jawaban pernyataan-pernyataan pada angket Gaya Belajar, data Kecerdasan Logika Matematika bersumber dari peserta didik yang diperoleh melalui tes soal matematika, sedangkan untuk Prestasi Belajar Matematika diperoleh melalui hasil UTS peserta didik kelas IV (empat). Ketiga data dalam penelitian selanjutnya dihitung dengan analisis statistik deskriptif, uji hipotesis dan analisis regresi ganda.

Tabel 1. Rangkuman Statistik Deskriptif

\begin{tabular}{|c|c|c|l|}
\hline Varians & $\begin{array}{c}\text { Gaya Belajar } \\
\text { Peserta }\end{array}$ & $\begin{array}{c}\text { Kecerdasan Logika } \\
\text { Matematika }\end{array}$ & $\begin{array}{l}\text { Prestasi } \\
\text { Belajar }\end{array}$ \\
\hline Mean & 61,30 & 16,35 & 71,25 \\
\hline Median & 61,16 & 17,2 & 73,58 \\
\hline Modus & 56,77 & 18,66 & 79,12 \\
\hline $\begin{array}{l}\text { Simp. } \\
\text { Baku }\end{array}$ & 5,95 & 5,24 & \\
\hline
\end{tabular}

Tabel 2. Ringkasan Hitung Uji Normalitas

\begin{tabular}{|c|r|c|c|c|}
\hline Kelompok & $\mathbf{n}$ & $\mathbf{X}^{\mathbf{2}}$ hitung & $\mathbf{X}$ '2 & Keterangan \\
\hline Gaya Belajar & 60 & 2,76 & 12,592 & Normal \\
\hline Kecerdasan Logika Matematika & 60 & 10,25 & 12,592 & Normal \\
\hline Prestasi Belajar Matematika & 60 & 10,412 & 12,593 & Normal \\
\hline
\end{tabular}

Tabel 3. Penolong Uji Barlet

\begin{tabular}{|c|l|c|c|c|c|}
\hline Variabel & $\mathbf{D k}$ & $\mathbf{S}^{\mathbf{2}}$ & $\mathbf{l o g} \mathbf{s}^{\mathbf{2}}$ & $(\mathbf{d k}) \log \mathbf{s}^{\mathbf{2}}$ & $\mathbf{d k}^{\mathbf{2}} \mathbf{2}$ \\
\hline Gaya Belajar & 59 & 34,7 & 1,540 & 100,3 & 2598,95 \\
\hline Kec. Logika Matematika & 59 & 28,5 & 1,45 & 94,4 & 1870,3 \\
\hline Prestasi Belajar & 59 & 168,8 & 2,227 & 141,6 & 9959,2 \\
\hline$\sum$ & 177 & & & 336,3 & 14239,65 \\
\hline
\end{tabular}

Pengaruh Gaya Belajar $\left(\mathrm{X}^{1}\right)$ dan Kecerdasan Logika Matematika $\left(\mathrm{X}^{2}\right)$ terhadap Prestasi Belajar Matematika (Y) Setelah dilakukan rangkaian penelitian, diperoleh hasil yaitu harga $F_{\text {hitung }}$ Gaya Belajar 
Jurnal Lebesgue : Jurnal Ilmiah Pendidikan Matematika, Matematika dan Statistika

Dwi Santi Wulandari, Indra Martha Rusmana

Volume 1, No. 2, Agustus 2020 hal.76-81

DOI Artikel : 10.46306/lb.v1i2.18

dan Kecerdasan Logika Matematika sebesar 1006,51, sedangkan harga $F_{\text {tabel }}$ pada taraf signifikasi $\propto=$ 0,05 adalah 3,17. Jika dibandingkan, terlihat bahwa harga $F_{\text {hitung }}$ lebih besar dari harga $F_{\text {tabel }}$ pada taraf signifikasi $\propto=0,05$. Hasil hipotesis tersebut sama dengan penelitian yang dilakukan Farida Mukti dalam jurnal Teknologi Pendidikan dalam judul "Perbedaan Pengaruh Gaya Belajar dan Kecerdasan Logika Matematika terhadap Prestasi Belajar Matematika kelas X di SMA Negeri 1 Ciseeng". Hasil perhitungan regresi ganda dengan sampel 63 siswa diperoleh $\mathrm{F}_{\text {hitung }}=9,51$ dan $\mathrm{F}_{\text {tabel }}=5,25$ pada taraf kepercayaan 0,05. Peserta didik yang memiliki Kecerdasan Logika Matematika yang baik tidak akan mengalami kesulitan dalam menghitung angka sederhana, akan tetapi peserta didik dengan kecerdasan logika matematika yang kurang akan mengalami kesulitan dalam memahami pelajaran matematika. Dalam memecahkan persoalan matematika tentu memerlukan konsentrasi yang tinggi. Kondisi untuk berkonsentrasi ini berhubungan dengan gaya belajar, sehingga peserta didik yang mengetahui gaya belajarnya akan mampu memahami pelajaran matematika yang sulit dan menemukan cara supaya kesulitan belajarnya dapat diatasi. Pengaruh Gaya Belajar ( $\left.\mathrm{X}^{1}\right)$ terhadap Prestasi Belajar Matematika (Y) Hasil penelitian menunjukkan gaya belajar peserta didik berpengaruh signifikan terhadap prestasi belajar matematika, hal ini dibuktikan harga $\mathrm{T}_{\text {hitung }}=2,39$ dan $\mathrm{T}_{\text {tabel }}=2,0042$. Hipotesis tersebut sama dengan penelitian yang dilakukan dahulu oleh Septi Kusti Hartini (2011) mahasiswi Program Studi Pendidikan Matematika Fakultas Teknik, Matematika dan Ilmu Pengetahuan Alam Universitas Indraprasta PGRI yang meneliti tentang "Pengaruh Gaya Belajar terhadap Prestasi Belajar Matematika Peserta Didik Bogor". Hasil penelitian tersebut menunjukkan terdapat pengaruh yang positif antara Gaya Belajar terhadap Prestasi Belajar Matematika. Hal ini dibuktikan dengan $\mathrm{Fh}>\mathrm{Ft}$ yaitu 8,81 > 3,17. Hasil penelitian dari pengujian hipotesis Simple Effect menunjukkan terdapat perbedaan prestasi belajar antara gaya belajar peserta didik. Seorang peserta didik dapat mamaksimalkan kemampuannya daam belajar sehingga prestasi belajar akan meningkat. Peserta didik yang bisa mengatasi kesulitan belajarnya bukan bearti lebih pandai. Namun ia mengetahui gaya belajarnya dengan baik, sehingga ia mampu mengatasi pelajaran yang sulit menjadi lebih mudah. Seluruh peserta didik memiliki perbedaan gaya belajar, untuk mengetahui perbedaan gaya belajar peserta didik dapat di lampiran. Penelitian ini dilakukan untuk melihat gaya belajar peserta didik bukan untuk membandingkan gaya belajar masing-masing peserta didik terhadap prestasi belajar matematika. Pengaruh Kecerdasan Logika Matematika $\left(\mathrm{X}^{2}\right)$ terhadap Prestasi Belajar Matematika (Y) Hasil penelitian menunjukkan Kecerdasan Logika Matematika peserta didik berpengaruh signifikan terhadap Prestasi Belajar Matematika, hal ini dibuktikan harga $T_{\text {hitung }}=7,18$ dan $\mathrm{T}_{\text {tabel }}=2,0042$. Berdasarkan data sebelumnya, maka kesimpulan yang diperoleh melalui analisis statistik secara empirik terbukti bahwa Gaya Belajar dan Kecerdasan Logika Matematika berpengaruh signifikan terhadap Prestasi Belajar Matematika. Hipotesis tersebut sama dengan penelitian yang dilakukan dahulu oleh Lucia Purwaningsih (2012) mahasiswi Program Studi Pendidikan Matematika Fakultas Teknik, Matematika dan Ilmu Pengetahuan Alama Universitas Indraprasta PGRI yang meneliti tentang "Pengaruh Kecerdasan Matematis Logis terhadap Prestasi Belajar Matematika". Hasil penelitian 
Jurnal Lebesgue : Jurnal Ilmiah Pendidikan Matematika, Matematika dan Statistika

Dwi Santi Wulandari, Indra Martha Rusmana

Volume 1, No. 2, Agustus 2020 hal.76-81

DOI Artikel : 10.46306/lb.v1i2.18

tersebut menunjukkan terdapat pengaruh yang positif antara Kecerdasan Matematis Logis terhadap

Prestasi Belajar Matematika. Hal ini dibuktikan dengan Fh > Ft yaitu 25,65 > 4,15. Hasil penelitian dari pengujian hipotesis Simple Effect menunjukkan terdapat perbedaan Prestasi Belajar antara Gaya Belajar Peserta Didik.

\section{KESIMPULAN}

Dalam penelitian ini, hasil perhitungan selanjutnya dibahas untuk mengetahui seberapa besar pengaruh variabel-variabel bebas terhadap variabel terikat. Secara bersama-sama terhadap Prestasi Belajar Matematika. Berdasarkan data sebelumnya, maka kesimpulan yang diperoleh melalui analisis statistik secara empirik terbukti bahwa Gaya Belajar dan Kecerdasan Logika Matematika berpengaruh signifikan terhadap Prestasi Belajar Matematika. Adanya pengaruh antara Gaya Belajar terhadap Prestasi Belajar Matematika disebabkan oleh beberapa faktor, baik faktor dari dalam maupun dari dalam luar peserta didik. Salah satu faktor ketika pengisian instrumen. Faktor lain yang memungkinkan yaitu tipe belajar peserta didik sendri. Hal ini dipengaruhi oleh cara mengajar atau metode pembelajaran yang diterapkan guru kepada peserta didik. Kecerdasan Logika Matematika berhubungan dengan angka dan berhitung, melibatkan pemecahan masalah secara sistematis, mempertimbangkan dan pola. Anak-anak yang terampil dalam matematika akan cepat memahami konsep matematika, senang melihat pola dan mengingat bilangan dalam jangka waktu yang lebih panjang.

\section{DAFTAR PUSTAKA}

Beni Junedi. 2013. Penggunaan Model Pembelajaran Generatif di Kelas VIII SMP. Unpublished Thesis. Padang: Universitas Negeri Padang.

Beni Junedi. 2017. The Influence Of Application Generative Learning Model Toward Mathematic Problem Solving Of Students At VIII Grade : A Personal View. Paper presented at the Proceeding 2nd International Seminar On Education Fakultas Tarbiyah Dan Ilmu Keguruan Institut Agama Islam Negeri Batusangkar.

Beni Junedi dan Juliana. 2019. Penerapan Strategi Pembelajaran Interaktif Dengan Teknik Pembelajaran Kolaboratif Send-A-Problem Terhadap Kemampuan Pemecahan Masalah Matematis Siswa Kelas IX SMP. MES: Journal of Mathematics Education and Science. (Online), Vol 4, No. 2, (https://jurnal.uisu.ac.id/index.php/mesuisu/article/view/1289), diakses 20 September 2019.

Kusuma, J. W., \& Hamidah. (2019). Pengaruh Model Pembelajaran ARIAS Dan Cooperative Script Terhadap Minat Dan Hasil Belajar Matematika. ANARGYA: Jurnal Ilmiah Pendidikan Matematika, 2(1), 64-69.

Supriyanti, A. (2020). PREDIKSI JUMLAH CALON PESERTA DIDIK BARU MENGGUNAKAN METODE DOUBLE EXPONENTIAL SMOOTHING DARI BROWN ( Study Kasus : SD Islam Al-Musyarrofah Jakarta ). Jurnal Lebesgue : Jurnal Ilmiah Pendidikan Matematika, Matematika Dan Statistika, 1(1), 56-62. https://doi.org/10.46306/lb.v1i1

Surjono, HermanDwi. 2017. Multimedia Pembelajaran Interaktif Konsep Dan Pengembangan. Yogyakarta : UNY Press.

Undang-undang Republik Indonesia Nomor 2 tentang Sistem Pendidikan Nasional. 1990. Jakarta: PT. Armas Duta Jaya

Zulhelmi, dkk. 2017. Pengaruh Media Pembelajaran Interaktif Terhadap Peningkatan Keterampilan Berpikir Kritis Siswa: Jurnal Pendidikan Sains Indonesia: Vol. 05, No. 01, hlm 73-80. 